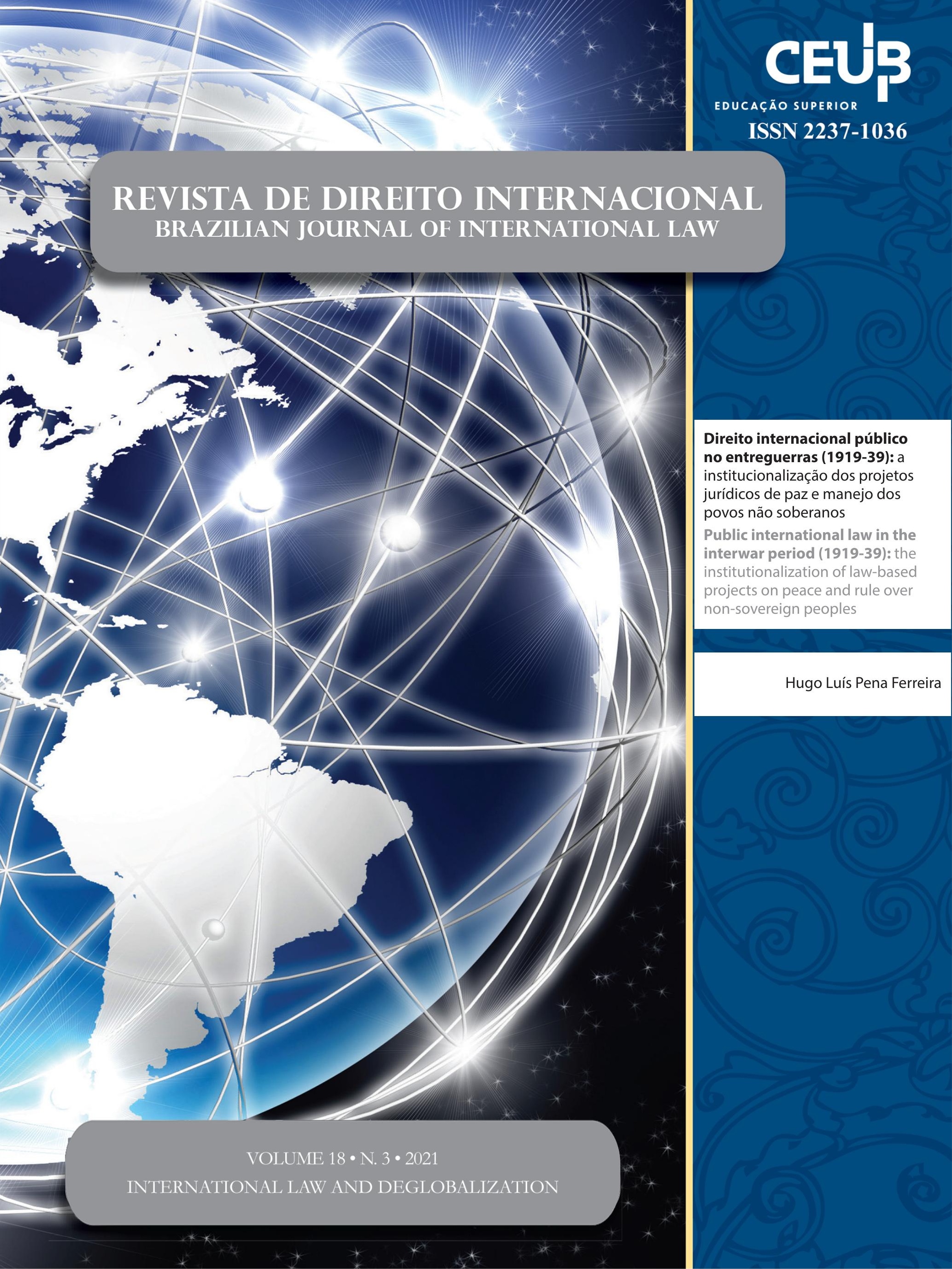




\section{Sumário}

Dossiê

EDITORIAL: INTERNATIONAL LAW AND DE-GLOBALIZATION 16 Ivette Esis, Jaime Tijmes e Juan Enrique Serrano

El régimen jurídico de la Inversión Extranjera Directa: ¿De la limitación a la desGLOBALIZACIÓN?

Ivette Esis Villarroel e Yoselyn Bermúdez Abreu

Desglobalização, Brexit e os novos acordos entre Reino Unido e União Europeia .34 Angela Limongi Alvarenga Alves e Daniel Freire e Almeida

FisCALIDAD Y DESGLOBALIZACIÓN EN UN MUNDO CRECIENTEMENTE UNILATERAL Julio César Muñiz Pérez

Covid, Covax e o Refluxo da Governança Global Salem Hikmat Nasser e Luiza Nogueira Papy

The International Monetary Fund and COVID-19: Old and New Challenges of a Post-World War II INTERNATIONAL INSTITUTION

Virdzhiniya Petrova Georgieva

Artigos Sobre outros temas

RULE OF LAW IN THE INTERNATIONAL ARENA: THE IMPORTANCE OF PRACTICES OF LEGALITY . 112 Angela Jank Calixto

THE WITHDRAWAL OF MEMBER-STATES FROM HUMAN RIGHTS COURTS: IS THE JUDICIALIZATION OF MEGA-POLITICS A NECESSARY CONDITION?. 132

Mikelli Marzzini Lucas Alves Ribeiro e Ernani Rodrigues de Carvalho Neto 
Princípio da precaução e mudança climática: uma análise do Acordo de Paris e das Conferências das Partes.

Jamille Bergamaschine Mata Diz e Carolina Mendonça de Siqueira

A INTERAÇÃo ENTRE OS ESPAÇOS CONSTITUCIONAIS NACIONAIS E INTERNACIONAIS E SEUS IMPACTOS NO SISTEMA DE FONTES DO DIREITO: AS LIÇÕES DA PROTEÇÃO COOPERATIVA DE DIREITOS HUMANOS E O CASO DA INTEGRAÇÃO EUROPEIA ...................................................... 173

Diego Fernandes Guimarães

WTO’s Engagement with National Law: Three Illustrations from India 193 Ravindra Pratap

GESTÃo MIGRATÓRIA E INTEGRAÇÃo REGIONAL: UMA ANÁLISE SOBRE A REGULAMENTAÇÃo NORmativa dos fluxos migratórios irregulares na União Europeia À luz do Novo Pacto Europeu sobre Migração e Asilo.................................................................. 212 João Mauricio Malta Cavalcante Filho e Eugênia Cristina Nilsen Ribeiro Barza

The African Regional Human and Peoples' Rights System: 40 years of progress and CHALLENGES. 232 Juan Bautista Cartes Rodríguez

The USMCA Sunset Clause 258 Jaime Tijmes-Ihl e Yvonne Georgina Tovar Silva

REFLEXÕES SOBRE A UNIVERSALIDADE DO DIREITO INTERNACIONAL DOS DIREITOS HUMANOS A RESPEITO DA PROTEÇÃO ÀS MULHERES 273 Érica Rios de Carvalho

A CRItical legal anAlysis OF GENDER EQUALITY IN INTERNATIONAL TRADE AgREEMENTS...287 Parul Shukla e Sheikh Sultan Aadil Huque

FEMinicídio, FEMicídio E Ódio NA AGENDA: o ASSASSinAto DAS MUlHERES NA AmÉriCA LATINA...... 309 Vinícius Ferreira Baptista

LEGAL IDEOLOGY IN THE CONTEXT OF DEVELOPMENT OF THE LEGAL STATE AND FORMATION OF THE CIVIL SOCIETY IN UKRAINE 
Direito INTERNACIONAL PÚBLICO NO ENTREgUERRAS (1919-39): A INSTITUCIONALIZAÇÃO DOS PROJETOS JURÍDICOS DE PAZ E MANEJO DOS POVOS NÃO SOBERANOS.

Hugo Luís Pena Ferreira

O Caso Gomes Lund (“Guerrilha Do Araguaia”) dez anos depois: Desafios para o cumPRIMENTO INTEGRAL PELO ESTADO BRASILEIRO

João Gabriel Archegas, Felipe Klein Gussoli e Vivian Cristina Lima López Valle

DiÁlogos museológicos: o Regime jurídico brasileiro e o Código de Ética do ConseLHo InTERnacional de Museus.

Paula Gonçalves do Carmo, Emerson Gabardo e Daniel Wunder Hachem 


\title{
Direito internacional público no entreguerras (1919-39): a institucionalização dos projetos jurídicos de paz e manejo dos povos não soberanos*
}

\author{
Public international law in the interwar \\ period (1919-39): the institutionalization of \\ law-based projects on peace and rule over non- \\ sovereign peoples
}

Hugo Luís Pena Ferreira**

\section{Resumo}

O direito internacional público não permaneceu o mesmo ao longo do tempo. O presente artigo focaliza a institucionalização como marca do direito internacional público no período compreendido entre as duas guerras mundiais (1919-39). O estudo enfatiza três processos de adensamento institucional: (i) a formação da concepção jurídica de segurança coletiva, embalada pelo idealismo wilsoniano, juridicamente fundamentada em tratado internacional e gerida pela Liga das Nações; (ii) a intensificação da criação de organizações internacionais e a postulação da jurisdição permanente e universal como modo superior de solução de controvérsias, que, por sua vez, estimulou a demanda por juristas internacionalistas para os quadros dos novos espaços criados e para a formação de novos jusinternacionalistas; e (iii) a conversão das relações metropolitanas com colônias e protetorados em uma formatação jurídica correspondente a um Sistema de Mandatos no bojo da Liga das Nações. A apresentação de referidas características permite perceber que o direito internacional público passou por transformações significativas no período do entreguerras. Nesse sentido, este estudo apresenta uma contribuição para a caracterização das singularidades do direito internacional nesse período. Desenvolveu-se este artigo, em bases bibliográficas, considerando-se as principais referências às contribuições de Martti Koskenniemi e Antony Anghie. Da abordagem proposta, emerge como argumento principal o aspecto de que a institucionalização do direito internacional público é a característica marcante do período. $\mathrm{O}$ adensamento institucional do direito internacional público não deve, no entanto, ser confundido com o sucesso do projeto jurídico como técnica de paz ou de emancipação de povos considerados não soberanos.

* Recebido em 11/09/2021

Aprovado em 13/12/2021

** Doutor em direito pela Universidade de Brasília (UnB). Mestre em direito pela Universidade Federal de Santa Catarina (UFSC). Professor do curso de direito da Universidade Federal de Jataí (UFJ).

Email: hlpfhugo@gmail.com
Palavras-chave: Direito internacional público; História do direito internacional; Institucionalização; Liga das Nações; Segurança coletiva; Sistema de mandatos. 


\section{Abstract}

Public International Law (PIL) has not remained the same over time. This paper focuses upon institutionalization as a feature of PIL in the time period between the first and the second world wars (1919-39). Three processes of institutional thickening are emphasized: (i) the formation of the law-based conception of collective security, bolstered by Wilsonian idealism, legally grounded in international treaty and managed by the League of Nations; (ii) the accrual in the creation of international organizations and in the perception of permanent and universal jurisdiction as superior means for dispute settlement, which in turn enhanced demand for international lawyers to fill positions in the newly created venues and in the training of new international lawyers; and (iii) the conversion of metropolitan relations with colonies and protectorates towards a legal framework comprising a mandates system embedded in the League of Nations. The assessment of such features favors realizing that PIL underwent significant changes in the interwar period. To this end, the paper presents a contribution towards the delineation of PIL's singularities in such period. Grounded in bibliographical sources, the research takes writings by Martti Koskenniemi and Antony Anghie as its main references. The main point arising from the approach adopted in the study is the perception of institutionalization of PIL as a discernible feature of the interwar period. Institutional thickening of international law should not, however, be mistaken as the (in)success of the legal project as technique for attaining peace or for the emancipation of non-sovereign peoples in such time period.

Keywords: Public international law; History of international law; Institutionalization; League of Nations; Collective security; Mandates System.

\section{Introdução}

O discurso jurídico sobre a relação entre Estados foi, até finais do século XIX, assunto de professores, filósofos e diplomatas. Com a publicação da Revue de droit international et de législation comparée, em 1868, o direito internacional público ganhou espaço próprio, apesar de misturado com o direito comparado e o direito interna- cional privado. ${ }^{1}$ A fundação do Institut de Droit International (IDI) em 1873, em Ghent, na Bélgica, foi passo decisivo para a emergência do direito internacional como campo autônomo. O IDI, que passou a abrigar o que se pode referir como primeiros juristas internacionalistas, definia seu propósito como favorecer o progresso do direito internacional, buscando tornar-se a "consciência jurídica do mundo civilizado". ${ }^{2}$ No projeto dos juristas de 1873, o conhecimento científico do direito internacional era meio apropriado para captar e expressar a consciência jurídica dos povos europeus. ${ }^{3}$ A criação da Revue e a formação do IDI podem ser encarados como espaços iniciais da articulação de uma linguagem jurídica autônoma com pretensões de ordenação das relações internacionais a partir da Europa.

No entanto, com o final da Primeira Guerra Mundial, o direito internacional público passou por um processo de significativa institucionalização. A nova concepção de segurança internacional do período entreguerras passou a negar a espontaneidade do sistema de balanço de poder (característico do concerto europeu ao longo do século XIX), e foi assentado em bases jurídicas. De modo a acompanhar esse impulso, a Liga das Nações foi concebida como instituição multilateral que abrigava projeto de paz fundado na normatividade jurídica. Os novos ares de multilateralismo ao fim da Primeira Guerra Mundial foram acompanhados da proliferação de organizações internacionais que demandavam juristas internacionalistas em seus quadros. No campo da solução de controvérsias, também houve adensamento da institucionalização: com ênfase na necessidade de estabelecer espaços judiciais e permanentes, em contraste com o modelo ad hoc e baseado em soluções não judiciais (mediação, arbitragem) anteriormente prevalentes. Por fim, as relações entre povos angloeuropeus e "os outros" também foram consideravelmente institucio-

${ }^{1}$ KOSKENNIEMI, Martti. The gentle civilizer of nations: the rise and fall of international law 1870 - 1960. Cambridge: Cambridge University Press, 2004. p. 13-14.

2 KOSKENNIEMI, Martti. The gentle civilizer of nations: the rise and fall of international law 1870 - 1960. Cambridge: Cambridge University Press, 2004. p. 41. Ao longo do artigo, foi feita a opção de manter todo o texto em um só idioma para tornar a leitura mais fluida. As citações de textos em língua estrangeira empregados no artigo foram traduzidas livremente para o português. Em alguns casos, para maior precisão, optou-se por traduzir e indicar, ao lado, a expressão no idioma original.

3 KOSKENNIEMI, Martti. The gentle civilizer of nations: the rise and fall of international law 1870 - 1960. Cambridge: Cambridge University Press, 2004. p. 51. 
nalizadas: não mais no domínio direto exercido pelas metrópoles sobre suas colônias, mas por um sistema internacionalmente institucionalizado na forma de Mandatos no âmbito da organização da Liga das Nações.

A caracterização encapsulada nos parágrafos anteriores permite perceber que o direito internacional público passou por transformações significativas no período compreendido entre a primeira e a segunda guerra mundiais. Muito embora a expressão "direito internacional público" seja utilizada para fazer referência a normatividades aplicáveis a períodos distintos, o contraste sugerido permite perceber que o direito internacional de finais do século XIX é diferente daquele do período entreguerras. Diante disso, o presente artigo busca abordar as principais características definidoras do direito internacional público entre 1919 e 1939. Nessa abordagem, emerge como argumento principal $\mathrm{o}$ aspecto de que a institucionalização ${ }^{4}$ do direito internacional público é a característica marcante do período. $\mathrm{O}$ adensamento institucional não deve, no entanto, ser confundido com o sucesso do projeto jurídico como técnica de paz ou de emancipação de povos; sucesso que não ocorreu. Ainda assim, embora estabelecida em bases muito contrastantes, a característica da institucionalização permanecerá válida para o período posterior à Segunda Guerra Mundial.

Por meio do recorte proposto neste artigo, não se delineiam as características do direito internacional em seu período de conformação como campo autônomo, que, acompanhando o entendimento de Koskenniemi, é tomado como ocorrente na porção final do século XIX. ${ }^{5}$ Não se trata, nesse sentido, de uma abordagem que proponha a comparação entre os dois períodos. Ainda assim, considerada a possibilidade de leitura em conjunto com outros textos que abordam o período antecedente, ${ }^{6}$

\footnotetext{
${ }^{4}$ Compreendem-se instituições, neste trabalho, como conjuntos persistentes e conectados de regras, sejam elas formais ou informais, que prescrevem papéis, constrangem ações e moldam expectativas. Ou seja, instituições têm implicações normativas para o comportamento dos atores. KEOHANE, Robert O. After hegemony: cooperation and discord in the world political economy. Princeton: Princeton University Press, 1984. p. 9. A menção a instituições engloba organizações internacionais, de modo coerente com o uso abrangente que Keohane faz desta expressão. KEOHANE, Robert O. After hegemony: cooperation and discord in the world political economy. Princeton: Princeton University Press, 1984. p. 22.

5 KOSKENNIEMI, Martti. The gentle civilizer of nations: the rise and fall of international law 1870 - 1960. Cambridge: Cambridge University Press, 2004.

${ }^{6}$ Ibid.; KAPLAN, Morton A.; KATZENBACH, Nicholas B. Fun-
}

a contribuição pretendida pelo artigo constitui a apresentação de elementos para a compreensão do percurso do direito internacional no período recortado. O procedimento de reunião e organização de elementos históricos adotado é acompanhado, como expediente analítico, da identificação de um aspecto transversal que permita caracterizar referido período: o processo de institucionalização do direito internacional público no período entreguerras. Referida institucionalização, como se poderá observar, foi embalada por um projeto de paz baseado numa concepção de segurança coletiva com tonalidades marcadamente jurídicas, acompanhado pela profusão de organizações internacionais, por um projeto judicial de solução de controvérsias, e pelo adensamento jurídico e transformação institucional das formas aplicadas ao domínio de potências angloeuropeias sobre outros povos.

Ainda quanto ao caráter da contribuição pretendida neste artigo, é importante observar que a caracterização de aspectos do percurso histórico do direito internacional público no período entreguerras traz marcas do encontro colonial. A literatura pós-colonial a respeito do direito internacional, em especial, implica a valorização de abordagens históricas a seu respeito, ao encarar as marcas do colonialismo e do imperialismo na formação da normatividade internacional como relevantes para a compreensão de elementos da agenda internacional no presente. $^{7}$ A centralidade e a relevância da preocupação com a história do direito internacional público no pre-

damentos politicos do direito internacional. Rio de Janeiro: Zahar, 1964; ANGHIE, Antony. Imperialism, sovereignty, and the making of international law. Cambridge: Cambridge University Press, 2004. A Revista de Direito Internacional conta com uma resenha da obra de Anghie: LEMOS, Fabrício José Rodrigues de; SARTORETTO, Laura Madrid. Resenha do livro Imperialism, Sovereignty and the Making of International Law, de Antony Anghie. Revista de Direito Internacional, Brasília, v. 15, n. 1, p. 305-308, 2018. Ainda sobre o tema: FERREIRA, Hugo Luís Pena. Formas jurídicas do encontro colonial: violência e hierarquias entre povos no direito internacional do século XIX e início do século XX. Revista Jurídica da UFERS A, v. 2, n. 3, p. 48-69, 2018.

${ }^{7}$ AFONSO, Henrique Weil. A era da humanidade: reflexões para a história do direito internacional. Revista de Direito Internacional, Brasília, v. 13, n. 3, p. 235-262, 2016. Para possibilidades de leitura de engastes e rearticulações de formas contemporâneas do direito internacional público e categorias correlatas ao encontro colonial, sugere-se a leitura de TRIGO, Germán Medardo Sandoval. La libre autodeterminación de los pueblos en el siglo XXI: Una aproximación de la historia del colonialismo y el neo-colonialismo desde los pueblos del tercer mundo en el derecho internacional. Revista de Direito Internacional, Brasília, v. 15, n. 1, p. 90-104, 2018. 
sente texto e na contribuição pretendida é, nesse sentido, lastreada no que aponta Galindo:

\begin{abstract}
a história do direito internacional serve para indagar ou mesmo romper com tradições estabelecidas, auxiliando o direito internacional a repensar os seus próprios fundamentos; consequentemente, ela permite a construção de diferentes alternativas possíveis para a organização jurídica internacional do presente e do futuro ao levar em consideração uma necessária prestação de contas devida para com as gerações passadas. ${ }^{8}$
\end{abstract}

Para realizar a caracterização proposta, o artigo está estruturado da seguinte maneira. A seguir, na seção 2, aborda-se a segurança coletiva como concepção juridicamente informada de segurança internacional. $\mathrm{Na}$ seção 3, apresenta-se o contexto de formação da Liga das Nações, com ênfase para o projeto representado pelo "idealismo wilsoniano". Na seção 4, delineiam-se adensamentos institucionais caracterizados pela profusão de organizações internacionais, pelo estabelecimento de uma jurisdição internacionalizada e permanente e pela acentuação da demanda por profissionais versados em direito internacional público para composição dos quadros dos espaços burocráticos criados naquele período. Na seção 5, aborda-se o direito internacional relativo aos não soberanos, com ênfase na substituição do modelo colonial pelo Sistema de Mandatos da Liga das Nações. Na seção 6, já com tonalidades conclusivas, aborda-se a derrocada do direito internacional do período como técnica de paz nas proximidades de 1939. Por fim, as considerações finais trazem uma síntese dos principais elementos apresentados.

\section{A transição do balanço de poder para o modelo juridicamente informado de segurança coletiva}

Até a Primeira Guerra Mundial, a concepção prevalente de segurança internacional era informada pelo balanço de poder, característico do concerto europeu estabelecido após as guerras napoleônicas, e que operou durante o século XIX 9 . Após a guerra, o novo projeto

${ }^{8}$ GALINDO, George Rodrigo Bandeira. Para que serve a história do direito internacional? Revista de Direito Internacional, Brasília, v. 12, n. 1, p. 338-354, 2015. p. 352.

9 Para Karl Polanyi, a duradoura efetividade do balanço de poder no contexto do século XIX esteve relacionada à emergência da haute finance - grandes investidores internacionais com ascendência so- para a segurança internacional passou a ser a fundado na noção de segurança coletiva. Em vários aspectos, essa concepção se assemelhava ao modelo anterior. Os dois sistemas: (i) só poderiam funcionar se não houvesse um só Estado mais poderoso que todos os outros juntos; (ii) pressupunham que a dissuasão funcionasse, ou seja, que os aspirantes à hegemonia deixariam de atacar por acreditar que a derrota seria inevitável em virtude do funcionamento do sistema; e (iii) compartilhavam visão sistêmica da segurança, no sentido de que o ataque de um agressor exigiria resposta conjunta, envolvendo países cujos territórios ou interesses diretos sequer tivessem sido diretamente afetados. ${ }^{10}$

Mas, em vários outros aspectos, os sistemas se diferenciavam. Primeiramente, a segurança coletiva objetivava a formação de apenas uma aliança universal, em que deveria haver ordem; enquanto o balanço de poder foi caracterizado por várias e instáveis alianças que competiam entre si. Em outros termos, a segurança coletiva espera comportamentos cooperativos dos Estados, ao passo que o balanço de poder deposita fé, apenas, em suas predisposições competitivas.

Em segundo lugar, há diferença naquilo que dispara a resposta do sistema de segurança. Na segurança coletiva, a agressão exigia a ação de todos os outros Estados. No balanço de poder, a agressão ou a conquista de território em si não eram concebidas como verdadeiras ameaças, mas sim a busca da hegemonia. Ganhos territoriais via guerras poderiam ocorrer, desde que não resultassem em grandes assimetrias de poder, diferenciando, excessivamente, um Estado dos demais.

Em terceiro, havia diferença no grau em que instituições estavam envolvidas. $\mathrm{O}$ sistema de balanço de poder, tendo lógica competitiva, dispensava instituições complexas ou formais para operá-lo, o que, em tese, poderia funcionar espontaneamente, embora o concerto europeu tenha contado com conferências concatenadas, entre as grandes potências, que funcionavam como colegiado para manejar questões territoriais na Europa.

bre governos - e seu "agudo interesse pela pą". Os negócios privados da haute finance seriam comprometidos pela eclosão de guerras entre grandes potências. "A vasta maioria dos portadores de titulos governamentais, bem como de outros investidores e comerciantes, seria a primeira a perder em tais guerras, especialmente se as moedas fossem afetadas." POLANYI, Karl. The great transformation: the political and economic origins of our time. 2. ed. Boston: Beacon Press, 2001 [1944]. p. 14.

${ }^{10}$ SHEEHAN, Michael. The balance of power: history \& theory. London/New York: Routledge, 2005. p. 155. 
Embora esse colegiado administrasse aspectos do balanço de poder, o sistema em si era baseado em reações espontâneas aos desequilíbrios de poder. As conferências auxiliavam a coordenação das grandes potências, mas não eram o alicerce do funcionamento do balanço de poder. Já o sistema de segurança coletiva pressupunha maior institucionalização. Nele, o compromisso de resposta coletiva à agressão foi transformado em obrigação jurídica. ${ }^{11} \mathrm{O}$ sistema foi organizado em torno do dever de considerar o ataque contra qualquer membro da aliança como ato de guerra contra todos os seus membros. ${ }^{12}$ A segurança nacional deixou de ser assunto que diga respeito a um Estado individualmente considerado, e passou a ser "responsabilidade coletiva, compartilhada pela comunidade internacional conjuntamente organizada." 13

Essa transição (do balanço de poder à segurança coletiva) pode ser lida como expressão do ganho de relevância do direito internacional para lidar com assuntos de segurança internacional, contexto em que o compromisso juridicamente estabelecido de resposta coletiva à agressão foi simbolicamente significativo. Esse ganho de relevância não deve ser confundido, no entanto, com o sucesso desta modalidade de discurso em reger as relações internacionais do período, como abordado mais adiante.

\section{0 idealismo wilsoniano e a formação da Liga das Nações}

A instituição concebida para abrigar o novo modelo de segurança internacional foi a Liga das Nações. Sua formação foi fortemente influenciada pelas ideias de Woodrow Wilson, presidente dos Estados Unidos à época das negociações do Tratado de Versalhes, que fixou os termos da paz entre as potências aliadas e as potências centrais (a principal das quais era a Alemanha), e que abrigou o Pacto da Liga das Nações como integrante de seu texto.

\footnotetext{
11 SHEEHAN, Michael. The balance of power: history \& theory. London/New York: Routledge, 2005. p. 158.

12 SHEEHAN, Michael. The balance of power. history \& theory. London/New York: Routledge, 2005. p. 153.

13 BOYLE, Francis Anthony. World politics and international law. Durham: Duke University Press, 1985. p. 53.
}

O wilsonianismo é caracterizado por sua postura idealista a respeito das relações internacionais. Ikenberry ${ }^{14}$ exemplifica o ponto com uma fala de Wilson. "O que objetivamos é o império do direito [rule of law], baseado no consentimento dos governados, e sustentado pelas opiniões organizadas da humanidade." Edward Carr se refere a essa postura como utópica, e identifica, em seu desprendimento com a realidade do funcionamento das relações internacionais, uma das causas para a derrocada do projeto de paz no período entreguerras. Carr $^{15}$ narra que Wilson, a caminho da Conferência de Paz, foi questionado se o projeto da Liga das Nações funcionaria, ao que ele respondeu: "se não funcionar, deve-se fazer com que funcione.” Wilson propunha que as interações entre Estados fossem conduzidas em bases jurídicas e morais. O direito deveria moldar a realidade. Sua postura era híbrida, entre o legalismo positivista e o moralismo: ao mesmo tempo que apelava para formas jurídicas como ordenadoras das relações internacionais, fundamentava em bases morais a necessidade de que essas formas existissem. ${ }^{16}$ Interações pacíficas eram percebidas como imperativo moral da humanidade em sua evolução civilizacional.

O projeto de Wilson era criar uma organização internacional de caráter universal, baseada em regras, e que vinculasse Estados democráticos. O balanço de poder seria substituído por mecanismos jurídicos de manejo de poder e de solução de disputas. ${ }^{17}$ A nova organização era postulada por Wilson como o meio para garantir a independência e a integridade territorial de todos os países. ${ }^{18}$

Ikenberry identificou três fatores na base da crença de Wilson de que a Liga funcionaria. O primeiro deles refere-se à percepção de que o mundo experimentaria uma revolução democrática: o czarismo havia caído na Rússia em 1917 e os principais estados vitoriosos na

14 IKENBERRY, John G. After victory: institutions, strategic restraint, and the rebuilding of order after major wars. Princeton: Princeton University Press, 2001. p. 127.

15 CARR, Edward Hallett. The twenty years' crisis 1919-1939: an introduction to the study of international relations., London: Macmillan \& Co., 1946. p. 8.

16 BOYLE, Francis Anthony. World politics and international law. Durham: Duke University Press, 1985. p. 52.

17 IKENBERRY, John G. After victory: institutions, strategic restraint, and the rebuilding of order after major wars. Princeton: Princeton University Press, 2001. p. 117.

${ }^{18}$ IKENBERRY, John G. After victory: institutions, strategic restraint, and the rebuilding of order after major wars. Princeton: Princeton University Press, 2001. p. 127. 
Primeira Guerra eram democracias. ${ }^{19} \mathrm{O}$ segundo fator é a opinião pública. A mensagem de Wilson tinha grande apelo popular, e Wilson, coerentemente com o pensamento liberal, acreditava que a opinião pública fosse capaz de moldar a condução da política internacional. ${ }^{20} \mathrm{O}$ terceiro fator foi a posição dos Estados Unidos como nova potência hegemônica, ocupando o lugar que antes era da Grã-Bretanha. Era a nova liderança econômica e militar. Os estoques americanos de ouro igualavam quase a metade das reservas de todo o mundo. ${ }^{21} \mathrm{~A}$ posição dos Estados Unidos fazia com que Wilson estivesse confiante em sua capacidade de influenciar a ordem no pós-guerra. Exemplo disto, trazido por Ikenberry ${ }^{22}$ refere-se à fala de Wilson a um de seus encarregados militares, em 1917, a respeito dos aliados: "quando a guerra acabar, nós poderemos forçá-los a nosso modo de pensar, porque até lá eles estarão, entre outras coisas, financeiramente em nossas mãos."

Mas as bases da crença de Wilson não se verificaram. Segundo Ikenberry, não ocorreu a revolução democrática mundial que Wilson esperava. "A maré de fermento revolucionário chegou ao topo no início de 1918, e a direção foi decisivamente conservadora à medida que a guerra caminhava para o fim." ${ }^{23}$ Paralelamente a isto, Wilson não conseguiu converter a ascendência norte-americana e o apelo moral à opinião pública em mudanças políticas concretas. Wilson postulava uma paz sem vencedores, mas França e Grã-Bretanha não dispensavam a imposição de reparações de guerra à Alemanha. Wilson desejava que o tratado de paz erigisse novas bases para as relações internacionais. Seus aliados desejavam punir a Alemanha e evitar novas possibilidades de sua ascensão militar. ${ }^{24}$ Como resultado, embora a

\footnotetext{
19 IKENBERRY, John G. After victory: institutions, strategic restraint, and the rebuilding of order after major wars. Princeton: Princeton University Press, 2001. p. 118.

${ }^{20}$ IKENBERRY, John G. After victory: institutions, strategic restraint, and the rebuilding of order after major wars. Princeton: Princeton University Press, 2001. p. 122.

${ }^{21}$ IKENBERRY, John G. After victory: institutions, strategic restraint, and the rebuilding of order after major wars. Princeton: Princeton University Press, 2001. p. 121.

${ }^{22}$ IKENBERRY, John G. After victory: institutions, strategic restraint, and the rebuilding of order after major wars. Princeton: Princeton University Press, 2001. p. 122.

23 IKENBERRY, John G. After victory: institutions, strategic restraint, and the rebuilding of order after major wars. Princeton: Princeton University Press, 2001. p. 162.

${ }^{24}$ KEYNES, John Maynard. As consequências econômicas da pa\%: São Paulo/Brasília: Imprensa Oficial do Estado/Universidade de Brasília, 2002.
}

Liga das Nações tivesse sido criada, aquilo que Wilson caracterizava negativamente como a velha política internacional mostrou-se persistente.

Os Estados Unidos não fizeram parte da Liga. O principal motivo foi a rejeição das implicações da segurança coletiva. Parte do porquê disto está relacionada às eleições legislativas nos Estados Unidos, que tanto no Senado quanto na House of Representatives resultaram em maioria republicana, sendo Wilson democrata. Wilson ficou isolado. ${ }^{25} \mathrm{~A}$ outra parte está relacionada às disposições constitucionais norte-americanas que atribuíam o poder de declaração de guerra ao Congresso e às implicações dos dispositivos do Pacto da Liga das Nações sobre este poder.

O artigo 10 do Pacto trazia a substância daquilo que deveria ser protegido, ao declarar que todos os membros da Liga tinham independência política e integridade territorial invioláveis. Fixava, a respeito desse ponto, o compromisso de ação coletiva contra a agressão externa a um membro da Liga. O artigo 11 reforçava essa posição, ao afirmar que qualquer guerra ou ameaça de guerra seria pertinente a toda a Liga. Os artigos 12 a 15 estabeleciam procedimentos para solução pacífica de controvérsias entre os membros da Liga, dentre os quais a diplomacia, negociações no Conselho da Liga, a arbitragem e submissão à Corte Permanente de Justiça Internacional (CPJI). E o artigo 16 prescrevia que, caso um membro da Liga recorresse à guerra em vez de adotar procedimentos de solução pacífica de controvérsias, isto seria considerado um ato de guerra contra todos os demais membros, que deveriam imediatamente impor sanções de interrupção total das relações comerciais, financeiras e de trânsito de pessoas com o Estado infrator. Caberia ao Conselho da Liga recomendar os meios militares, navais e aéreos com os quais os membros deveriam contribuir para fins de resposta armada. O artigo, também, previa a possibilidade de exclusão do infrator.

No Senado norte-americano, além dos senadores que partilhavam da postura isolacionista a respeito da política externa, a proposta da Liga encontrou resistência por ter sido recebida como a transferência do poder de declaração de guerra do Congresso a uma organização internacional. Em outros termos, o Senado rejeiPrinceton University Press, 2001. p. 149. 
tou o engajamento dos Estados Unidos no sistema de segurança coletiva. Wilson argumentou que o tratado estabelecia que os Estados Unidos seriam membros do Conselho, a quem caberia decidir questões envolvendo uso da força. Ali, os Estados Unidos teriam poder de veto sobre a decisão. Em decorrência disto, não haveria possibilidade de que os Estados Unidos fossem empurrados a guerras indesejadas. ${ }^{26}$ Ainda assim, a argumentação de Wilson não satisfez o Senado (até mesmo porque não deixava de implicar transferência do poder de decisão sobre a guerra do Congresso para os representantes norte-americanos no Conselho da Liga), que rejeitou a ratificação. ${ }^{27}$ A não participação dos Estados Unidos na Liga é apontada como fator para seu fracasso na década de $1930 .^{28}$

De toda forma, o projeto de segurança coletiva é uma manifestação da projeção do direito internacional para a área da segurança internacional e de seu processo de institucionalização, a sinalizar o ganho de sua relevância no período posterior à Primeira Guerra Mundial.

\section{Organizações internacionais, jurisdição permanente e os novos postos de trabalho para juristas internacionalistas}

O Tratado de Versalhes, embora sem os Estados Unidos, foi levado a cabo pelos demais aliados. Como resultado, criaram-se novas instituições: além da Liga das Nações, o Tratado estabeleceu a Organização Internacional do Trabalho (OIT) e a Corte Permanente de Justiça Internacional (CPJI).

Sediada em Genebra, na Suíça, e funcionando desde 1919, a presença da OIT no cenário internacional foi significativa de transformações socioeconômicas substanciais. Seu funcionamento incorporou a presença de classes, e não somente da representação política estatal: para além de representantes do Estado, a organização opera com representantes da classe patronal e

\footnotetext{
${ }^{26}$ IKENBERRY, John G. After victory: institutions, strategic restraint, and the rebuilding of order after major wars. Princeton: Princeton University Press, 2001. p. 153.

${ }^{27}$ IKENBERRY, John G. After victory: institutions, strategic restraint, and the rebuilding of order after major wars. Princeton: Princeton University Press, 2001. p. 154.

28 SHEEHAN, Michael. The balance of power: history \& theory. London/New York: Routledge, 2005. p. 161.
}

dos trabalhadores. A instituição parece poder ser encarada como reflexo das pressões domésticas por melhoria das condições de trabalho e das condições sociais, decorrentes da influência da expansão das democracias de massa, da industrialização e da urbanização. Nesse sentido, essa nova fase do direito internacional também se dedicou "à promoção de objetivos sociais", sendo "informada e moldada por desenvolvimentos sociais e que refletiam as realidades reveladas pela sociologia e a ciência política". ${ }^{29}$

A CPJI, embora prevista no Tratado de Versalhes, só começou a operar em 1922, em Haia. Suas funções eram consultivas e de solução de casos contenciosos. A CPJI poderia tanto emitir opiniões consultivas a partir de questões formuladas pelo Conselho ou Assembleia da Liga das Nações quanto resolver disputas entre Estados. Nesse último aspecto, sua jurisdição estava restrita a assuntos de "natureza jurídica" (como em oposição à "natureza política", o que permitia válvula de escape ao exercício de sua jurisdição), e dependia da aceitação dos Estados. Estes poderiam reconhecer, diretamente, a jurisdição compulsória da Corte (que poderia ser feita com ou sem reservas), comprometer-se por cláusulas jurisdicionais em tratados, ou firmar acordos especiais com o objetivo específico de submeter uma controvérsia à CPJI. Seus juízes eram eleitos pelo Conselho e pela Assembleia da Liga das Nações, e deveriam ser representativos "das principais formas de civilização e dos principais sistemas jurídicos do mundo" (Art. 9). A tonalidade civilizadora da Corte também estava presente em seu artigo 38, que menciona entre as fontes de direito os "princípios gerais de direito reconhecidos pelas nações civilizadas." Essas distinções remetem a discussões a respeito da distinção cultural e racial sobre a qual o direito internacional europeu foi fundado, e que é indissociável do modo como esse direito se universalizou. $^{30}$

A CPJI foi representativa da demanda por solução pacífica de controvérsias nesse período do direito internacional. $\mathrm{O}$ recurso à arbitragem internacional já havia aumentado desde o final do século XIX, com a Corte

\footnotetext{
29 ANGHIE, Antony. Imperialism, sovereignty, and the making of international law. Cambridge: Cambridge University Press, 2004. p. 128.

30 ANGHIE, Antony. Imperialism, sovereignty, and the making of international law. Cambridge: Cambridge University Press, 2004; FERREIRA, Hugo Luís Pena. Formas jurídicas do encontro colonial: violência e hierarquias entre povos no direito internacional do século XIX e início do século XX. Revista Jurídica da UFERSA, v. 2, n. 3, p. $48-69,2018$
} 
Permanente de Arbitragem, de 1899. Mas a criação da CPJI representou passo além na concepção do direito como ferramenta de ordem nas relações internacionais: o direito como projeto ou técnica de paz. Esse projeto englobou, além da solução pacifica de controvérsias, também a proscrição da guerra e o compromisso jurídico de resposta coletiva à agressão como partes integrantes do direito internacional. A afirmação de proscrição da guerra precisa, porém, ser aproximada com ressalvas. A Liga das Nações não a excluiu das relações internacionais, nem mesmo no plano do dever ser: a guerra é resposta lícita à agressão contra a independência e a integridade territorial, e continuava cabendo a cada membro interpretar o significado destas categorias. Além disso, o recurso à guerra era lícito diante da falha dos mecanismos de solução pacífica. O Pacto Kellogg-Briand, de 1928, ficou conhecido como sendo o documento que positivou a proibição da guerra. Mas, sob o título de autodefesa ou legítima defesa, cujo sentido estava aberto à interpretação de cada Estado, ${ }^{31}$ a guerra continuava a poder ser conduzida com respaldo jurídico. Essas aberturas interpretativas - sempre relegadas ao arbítrio dos Estados, individualmente - estiveram associadas à derrocada do direito internacional no período entreguerras como técnica de paz. Ainda assim, os juristas internacionalistas acreditavam nesse projeto, e era essa a linguagem falada nas organizações internacionais do momento. Em outros termos, a diplomacia do interesse nacional juridicamente indomado perdeu espaço, entre os juristas, para a perspectiva de ordenação jurídica das relações internacionais. O fato de esse desdobramento não ter se refletido efetivamente no comportamento dos Estados é indício do insucesso do projeto de capturar a diplomacia por formas jurídicas.

A presença acentuada de organizações multilaterais no direito internacional do pós-guerra criou ambientes de trabalho para os juristas internacionalistas. Entre 1919 e 1925, os agentes de organizações internacionais passaram de cerca de uma centena a milhares, trabalhando na Liga das Nações, na Corte Permanente de Justiça Internacional e na Organização Internacional do Trabalho. As novas organizações geraram demanda por profissionais inclinados à causa universalista do direito internacional, ou seja, com orientação cosmopolita. Este é o novo mercado direto de postos de trabalho. In-

31 KOSKENNIEMI, Martti. The gentle civilizer of nations: the rise and fall of international law 1870 - 1960. Cambridge: Cambridge University Press, 2004. p. 377. diretamente, criou-se "um mercado sem precedentes de consultoria em assuntos públicos internacionais." 32 Diversos tratados continham cláusulas de solução pacífica de controvérsias, fomentando a demanda por expertise em mediação, arbitragem e disputas judiciais. Segundo Sacriste e Vauchez $z^{33}$, esse fenômeno dos anos 1920 está associado ao ganho de força que o direito internacional teria recebido naquele momento. Como parte de uma "economia da reputação" que veio à tona no período, exigia-se desses profissionais tanto habilidades técnicas no uso do direito internacional quanto independência dos jogos políticos e diplomáticos.

Essa economia da reputação favorecia os profissionais formados nos diversos institutos de direito internacional. Os provedores de "crédito simbólico" eram variados, e integravam aquilo que Sacriste e Vauchez descrevem como um "boom de cosmopolitismo acadêmico." "34 Além do Institut de Droit International de Ghent, de 1873, funcionavam como centros de formação a Hague Academy of International Law, fundada em 1913; o Institut de Hautes Études Internationales de Paris, de 1923; e o Institut de Hautes Études Internationales de Genève, de 1926. Todos eles adotavam retórica universalista e currículo voltado ao recrutamento para as novas posições institucionais multilaterais. ${ }^{35} \mathrm{~A}$ "moldura cognitiva compartilhada" por esses institutos, e incorporada pelos internacionalistas, envolvia a "técnica jurídica de paz”. A obtenção da paz pelo direito era postulada como "único método legítimo e eficiente de impor um conjunto de obrigações e restrições à política do poder." 36

A moldura cognitiva dos internacionalistas da época era caracterizada por certos pontos fundamentais. ${ }^{37} \mathrm{O}$

32 SACRISTE, Guillaume; VAUCHEZ, Antoine. The force of international law: lawyers' diplomacy on the international scene in the 1920s., Law \& Social Inquiry, v. 32, n. 1, p. 83-107, 2007. p. 88.

33 SACRISTE, Guillaume; VAUCHEZ, Antoine. The force of international law: lawyers' diplomacy on the international scene in the 1920s., Law \& Social Inquiry, v. 32, n. 1, p. 83-107, 2007. p. 99.

34 SACRISTE, Guillaume; VAUCHEZ, Antoine. The force of international law: lawyers' diplomacy on the international scene in the 1920s., Law \& Social Inquiry, v. 32, n. 1, p. 83-107, 2007. p. 93.

35 SACRISTE, Guillaume; VAUCHEZ, Antoine. The force of international law: lawyers' diplomacy on the international scene in the 1920s., Law \& Social Inquiry, v. 32, n. 1, p. 83-107, 2007. p. 89.

36 SACRISTE, Guillaume; VAUCHEZ, Antoine. The force of international law: lawyers' diplomacy on the international scene in the 1920s., Law \& Social Inquiry, v. 32, n. 1, p. 83-107, 2007. p. 85.

37 A caracterização dessa moldura cognitiva conta com nuances. Quanto aos jusinternacionalistas estadunidenses do período do entreguerras, por exemplo, a caracterização proposta por Sacriste 
primeiro deles é a proposta de uso do método científico e da racionalidade como ferramenta mais eficiente para superar o viés das origens nacionais e dos pontos de vista políticos. Nesse sentido, nota-se a influência da crença positivista na possibilidade de objetividade e neutralidade no fazer ciência. O segundo ponto é a crença na superioridade do modo judicial de solução de conflitos. E o terceiro, a ele associado, é a afirmação da necessidade de jurisdição permanente, com competência universal e compulsória, apresentada como mecanismo de solução de controvérsias superior à conciliação ou à arbitragem. $\mathrm{O}$ mais curioso desses pontos é, sem dúvida, o sentido de desenvolvimento gradual do direito como projeto de paz, que permitia apresentar os fracassos do direito internacional em domar a política do poder como parte de lenta caminhada rumo ao plano superior de rule of law. Por exemplo, a falha na aceitação universal da jurisdição da CPJI era justificada por membros do IDI como "estágio necessário" na construção da ordem, "seguindo os estágios iniciais de anarquia (primeiro passo), balanço de poder (segundo passo), conciliação política (terceiro passo), arbitragem jurídica (quarto passo) e jurisdição permanente (passo atual)." ${ }^{38}$ Os primeiros passos são mais informados pela política, ao passo que os últimos, pelo direito.

A criação de novas oportunidades de trabalho no plano supranacional conviveu com as posições acadêmicas e políticas dos internacionalistas em seus países. A época foi marcada pela "diferenciação e especialização da prática do direito internacional", associada à maior es-

e Vauchez parece ser mais adequada ao grupo que Hatsue Shinohara categoriza como "reformadores", em contraste com o dos "tradicionalistas". Os reformadores, como Wright, Fenwick e Hudson, "acreditavam na existência de uma sociedade internacional, na qual a guerra deveria ser abolida e em que uma ordem internacional pacífica e equitativa prevaleceria. [...] Em especial, os reformadores encaravam tratados multilaterais como o Pacto da Liga das Nações, o Tratado das Nove Potências e o Pacto Kellogg-Briand como configuradores de um código jurídico fundamental da sociedade internacional." De modo contrastante, para os tradicionalistas - que emulavam o direito internacional do século XIX —, como Baty, Moore e Borchard, "o papel do direito internacional estava restrito à regulação de direitos e obrigações específicos entre as nações. $\mathrm{O}$ direito não deveria lidar com assuntos como guerra, desarmamento ou segurança coletiva, nem deveria definir guias para a conduta das nações. Assim, os tradicionalistas não consideravam que tratados multilaterais tais como o Pacto fossem juridicamente vinculantes, mas meras declarações de intenções políticas [policy]." SHINOHARA, Hatsu. US international lanyers in the interwar years: a fogotten crusade. Cambridge: Cambridge University Press, 2012. p. 220.

38 SACRISTE, Guillaume; VAUCHEZ, Antoine. The force of international law: lawyers' diplomacy on the international scene in the 1920s., Law \& Social Inquiry, v. 32, n. 1, p. 83-107, 2007. p. 104. truturação jurídica da política internacional na época. ${ }^{39}$ Sacriste e Vauchez identificam quatro padrões de carreiras. No plano nacional, continuou a haver posições para experts nacionais (abrangendo tanto jurisconsultos quanto gentlemen-politicians of law: juristas internacionalistas que assumiam cargos políticos) e para acadêmicos que produziam doutrina nacional. No plano internacional, abriu-se maior espaço para os international legal experts e para juristas acadêmicos com produção cosmopolita, como Kelsen, Jellinek e outros. ${ }^{40}$

Era comum que juristas assumissem múltiplas posições, nacionais e internacionais, acadêmicas e de expertise. O argumento principal de Sacriste e Vauchez é o de que a força do direito internacional nos anos 1920 não decorreu de seus atributos intrínsecos, mas da demanda por profissionais pelas novas instituições multilaterais e do capital social da comunidade jurídica que ocupou estas novas posições, animada por um espírito cosmopolita. A nuance consiste em que, ocupando as mais variadas posições, os juristas internacionalistas estavam situados de modo a influenciar a demanda por instituições multilaterais e solução pacífica de controvérsias (ocupando posições de Estado, ou provendo expertise jurídica para a política externa) e, ao mesmo tempo, a prover a força de trabalho para satisfazê-la (cargos burocráticos em instituições multilaterais, arbitragem e CPJI, bem como a formação acadêmica de novos juristas internacionalistas).

39 SACRISTE, Guillaume; VAUCHEZ, Antoine. The force of international law: lawyers' diplomacy on the international scene in the 1920s., Law \& Social Inquiry, v. 32, n. 1, p. 83-107, 2007. p. 92.

40 SACRISTE, Guillaume; VAUCHEZ, Antoine. The force of international law: lawyers' diplomacy on the international scene in the 1920s., Law \& Social Inquiry, v. 32, n. 1, p. 83-107, 2007. Em conexão com esse ponto, Martti Koskenniemi aponta: "Os escritos de Hersch Lauterpacht, Alfred Verdross e Hans Kelsen, dentre outros autores, estabeleceram uma interpretação altamente influente dos erros das doutrinas do pré-guerra. Ao associar o fracasso dessas doutrinas à sua proximidade excessiva das políticas de Estado e do interesse nacional e ao defender a autonomia das regras jurídicas internacionais, esses estudiosos abriram caminho para o estabelecimento do que se poderia chamar de abordagem normativa ao direito internacional, salientando assim a normatividade do direito e sua capacidade de oposição à política estatal como a chave para sua relevância restritiva." KOSKENNIEMI, Martti. Entre a apologia e a utopia: a política do direito internacional. Revista de Direito Internacional, Brasília, v. 15, n. 1, p. 10, 2018. 


\section{0 direito internacional dos não soberanos: Sistema de Mandatos e colonialismo}

O Sistema de Mandatos foi criado como parte do Pacto da Liga das Nações. Foi a nova forma de administração de colônias e protetorados das potências derrotadas na Primeira Guerra Mundial, sobretudo Alemanha e Turquia. As analogias do direito privado, elementos bastante salientes na formação do direito internacional clássico, foram isomorficamente preservadas ${ }^{41}$ na nova configuração do direito internacional: nos mandatos, continuou havendo a ideia de que uma potência exerce tutela sobre um povo incapaz, para os atos da vida civil, ou, nesse caso, a vida internacional. Afinal, o Pacto afirmava que os mandatos seriam estabelecidos em territórios "habitados por povos ainda não capazes de se manterem sozinhos nas condições árduas do mundo moderno." (Art. 22.4) A diferença formal entre as categorias anteriores de colônia e protetorado e o novo Sistema de Mandatos consistia no fato de que, nas primeiras, a administração era feita em nome da própria potência colonial, ao passo que, no segundo, a administração recebia rótulo distinto. Era encargo da potência mandatária, mas exercida em nome da Liga das Nações. Em nome, portanto, de uma organização internacional representativa da comunidade de nações. ${ }^{42}$ Tratava-se de nova vestimenta jurídica para a preservação de práticas coloniais: "o sistema de mandatos, ao adotar o conceito de tutela, justificava o gerenciamento de povos colonizados apresentando-o como guiado pela preocupação com os interesses nativos e pelo desejo de promover

\footnotetext{
${ }^{41}$ Nesse sentido, Koskenniemi aponta que, em relação à formação do direito internacional público, "a doutrina da soberania exerce um papel análogo ao da liberdade individual no discurso de legitimação doméstica." O autor destaca a busca por um "Estado de Direito internacional" como projeção do Estado de Direito no plano doméstico. KOSKENNIEMI, Martti. Entre a apologia e a utopia: A política do direito internacional. Revista de Direito Internacional, Brasília, v. 15, n. 1, p. 7-14, 2018. Para além da categoria de soberania, o procedimento de projeção das formas da jurisprudência doméstica para o plano internacional esteve envolvido em múltiplas analogias, como destaca Marcus Faro de Castro: “estado/indivíduo; tratado/ contrato; soberania territorial/propriedade; protetorados/incapacidade civil. " CASTRO, Marcus Faro de. Formas jurídicas e mudança social: interações entre o direito, a filosofia, a política e a economia. São Paulo: Saraiva, 2012. p. 182.

${ }^{42}$ KOSKENNIEMI, Martti. The gentle civilizer of nations: the rise and fall of international law 1870 - 1960. Cambridge: Cambridge University Press, 2004. p. 173.
}

seu autogoverno, em vez de desejos egoístas da potência colonizadora." $" 43$

O critério de discriminação cultural e racial forneceu a base para a diferenciação de três tipos de mandatos ${ }^{44}$ : classes A, B e C. Os mandatos classe A correspondiam a antigas partes do Império Turco, e compreendiam territórios do Oriente Médio: Palestina, Iraque, Síria, Líbano e Transjordânia. Esses territórios eram considerados relativamente mais civilizados que os demais, mais capazes de autogoverno, e deveriam se tornar independentes logo. Eram administrados mais analogamente aos protetorados do que às colônias: contavam com governo local próprio. Mas a promessa de independência foi elusiva. Somente o Iraque conseguiu independência durante o Sistema de Mandatos. ${ }^{45}$ Os demais, apenas após a Segunda Guerra, e a Palestina permanecem no limbo jurídico até o momento de escrita do presente texto, seu reconhecimento pleno ainda sendo objeto de disputa.

Os mandatos classe B compreendiam povos considerados como de estágio de civilização inferior, posicionados sobretudo na região central da África, e anteriormente pertencentes à Alemanha. Incluíam Camarões, Ruanda, e territórios correspondentes à atual Tanzânia e Togo. Diferentemente da classe A, que contava com autogoverno. Esses territórios eram administrados diretamente pela potência mandatária. Nenhum destes conseguiu se libertar na vigência do Sistema de Mandatos.

43 ANGHIE, Antony. Imperialism, sovereignty, and the making of international law. Cambridge: Cambridge University Press, 2004. p. 140.

${ }^{44} \mathrm{O}$ artigo de Thomas Skouteris a respeito do pensamento de Stelios Seferiades, jusinternacionalista grego atuante no período do entreguerras, estabelece diretamente a conexão entre a concepção de estratificações de nações segundo o grau de civilização e a configuração do Sistema de Mandatos da Liga das Nações. Para Seferiades, o mundo seria dividido em três categorias de Estados: civilizados, semibarbáricos e selvagens. SKOUTERIS, Thomas. The vocabulary of progress in interwar international law: an intellectual portrait of Stelios Seferiades. European Journal of International Law, v. 16, n. 5, p. 851-853, 2006.

45 Pedersen adverte que a independência do Iraque não deve ser atribuída à intencionalidade da Comissão de Mandatos. "A 'emancipação' do Iraque, por exemplo — ou, digamos, a criação de um Estado cliente no Iraque - foi um projeto conjunto de nacionalistas iraquianos e oficiais britânicos que buscavam alcançar um arranjo mutuamente benéfico, um que também limitasse a supervisão internacional, acesso econômico e interferência diplomática. A Comissão de Mandatos não gostava do arranjo, sendo profunda e justificadamente cética dos motivos britânicos, além de igualmente duvidosa de que povos não ocidentais estivessem prontos para o autogoverno." PEDERSEN, Susan. The guardians: the League of Nations and the crisis of empire. Oxford: Oxford University Press, 2015. p. 402 
A classe $\mathrm{C}$ era composta de territórios de população esparsa, de território pequeno, que eram remotos ou contíguos ao território do mandatário. Entraram nessa categoria a Namíbia e as Ilhas do Pacífico, como Samoa e Nova Guiné. Eram administrados como se fossem porções do território do próprio mandatário, e sob as leis deste. ${ }^{46}$ Tampouco esses territórios deixaram de ser mandatos na vigência da Liga das Nações. ${ }^{47}$

Depreende-se que todas essas classificações foram reformulações de categorias jurídicas anteriores, adaptadas para fazer frente a uma ordem jurídica que, discursivamente, foi institucionalizada em torno do conceito de comunidade internacional. Assim, os mandatos "A" eram a reedição do protetorado. Os mandatos "B", das colônias. E os mandatos "C", da conquista por anexação. Em todos esses casos, a diferença foi formal ou discursiva e consistia no fato de que o novo jugo passou a ser feito em nome do interesse coletivo da comunidade internacional de Estados e de maneira institucionalizada, abrigada por uma organização internacional e por tratado.

Segundo o artigo 22 do Pacto da Liga das Nações, o bem-estar e o desenvolvimento desses povos formavam uma "missão sagrada da civilização". Que obrigações jurídicas estariam implicadas nessa missão civilizadora? De acordo com Anghie, ${ }^{48}$ havia obrigações substantivas e procedimentais. A parte substantiva referia-se ao dever de prover bem-estar moral e material, numa reedição da fórmula da Conferência de Berlim, responsável pela partição de territórios do continente africano entre potências europeias em finais na porção final do século XIX. Mais uma vez, o comércio e a incorporação de instituições europeias tiveram a dupla função de provê-los. Curiosamente, não houve proscrição do uso de trabalho forçado pelas potências mandatárias: "projetos de infraestrutura eram de tal importância que o Conselho da Liga permitia trabalho compulsório ou forçado como remuneração por 'trabalhos e serviços públicos essenciais"', como ferrovias, estradas e portos. ${ }^{49}$

\footnotetext{
46 ANGHIE, Antony. Imperialism, sovereignty, and the making of international law. Cambridge: Cambridge University Press, 2004. p. 122.

47 HILLIER, Tim. Sourcebook on public international law. London: Cavendish Publishing, 1998. p. 198; KOSKENNIEMI, Martti. The gentle civilizer of nations: the rise and fall of international law $1870-1960$. Cambridge: Cambridge University Press, 2004. p. 171.

48 ANGHIE, Antony. Imperialism, sovereignty, and the making of international law. Cambridge: Cambridge University Press, 2004. p. 120.

49 ANGHIE, Antony. Imperialism, sovereignty, and the making of international law. Cambridge: Cambridge University Press, 2004. p. 167.
}

Cabe, neste, breve parêntese a respeito do trabalho nativo. A inserção de instituições europeias e do "mercado" nos mandatos contribuía para minar as estruturas tradicionais das sociedades locais. Quando isso acontecia, pessoas que estavam engajadas no modo de vida tradicional e de subsistência passavam a ser "força de trabalho livre". ${ }^{50}$ Depreende-se que a supressão das instituições tradicionais locais era importante para a criação de força de trabalho do tipo "produtivo", capaz, portanto, de engajar-se tanto na produção de excedentes comercializáveis como no tipo de consumo que é conectado a uma cadeia produtiva das sociedades de mercado, e não à mera subsistência. Nota-se a direção da relação entre progresso, mercado ou comércio, e instituições locais. "O desenvolvimento econômico era o sistema supremo ao qual todas as instituições estavam subordinadas e que todas as outras instituições deveriam servir." ${ }^{51}$ Saltam aos olhos as notas coloniais desta concepção de progresso.

Entre as obrigações procedimentais das potências mandatárias, estava a submissão de relatório anual ao Conselho da Liga. O relatório era apreciado pela Comissão Permanente de Mandatos da Liga. Essa comissão também instituiu sistema pelo qual as populações dos territórios sob mandato poderiam submeter-lhe petições. No entanto, isto somente poderia ser feito via potência mandatária, conferindo-lhe, na prática, o poder de filtrar o que chegava aos olhos da Liga. ${ }^{52}$ Além disso, havia a previsão de que controvérsias a respeito do exercício do mandato fossem submetidas à CPJI. Porém, os territórios sob mandato não tinham personalidade jurídica para fazê-lo: apenas outro Estado poderia ingressar com o processo para questionar as práticas do Estado mandatário. Não é surpreendente, portanto, que os mecanismos de supervisão não tenham sido bem-sucedidos. ${ }^{53}$

Cabe, a esse respeito, uma ressalva. Para Susan Pedersen, porém, o Sistema de Mandatos da Liga das $\mathrm{Na}-$ ções acabou por servir como uma "esfera de contestação colonial". ${ }^{44}$ Por um lado, o aspecto geopolítico da

\footnotetext{
50 ANGHIE, Antony. Imperialism, sovereignty, and the making of international law. Cambridge: Cambridge University Press, 2004. p. 171.

51 ANGHIE, Antony. Imperialism, sovereignty, and the making of international law. Cambridge: Cambridge University Press, 2004. p. 173-4. 52 ANGHIE, Antony. Imperialism, sovereignty, and the making of international law. Cambridge: Cambridge University Press, 2004. p. 175.

53 ANGHIE, Antony. Imperialism, sovereignty, and the making of international law. Cambridge: Cambridge University Press, 2004. p. 123.

${ }^{54}$ PEDERSEN, Susan. The guardians: the League of Nations and
} 
configuração do Sistema de Mandatos como um arranjo entre potências imperiais do período entreguerras é importante, ${ }^{55}$ e permite compreender a intenção destas em manter o jugo colonial sob outra roupagem. Por outro, "se os conflitos geopolíticos desses anos moldaram o caráter do sistema de mandatos, as pressões geradas pelo que podemos chamar de dinâmica de internacionalização também importaram." ${ }^{56}$ Assim, quanto ao manejo dos não soberanos:

o que era novo e transformador no sistema de mandatos não era a retórica da missão civilizadora, que todas as potências imperiais utilizavam, nem mesmo as práticas de domínio aplicadas no terreno [ $\mathrm{ru}$ ling practices on the ground, que espelhavam aquelas das colônias. O que era novo, em vez disso, era o aparato e o nível de diplomacia internacional, publicidade, e 'conversa' [talk] que o sistema trouxe à tona. ${ }^{57}$

A internacionalização e o adensamento da institucionalização das práticas coloniais sob a Liga das $\mathrm{Na}$ ções implicaram efeitos não desejados pelas potências imperiais europeias. Pedersen valoriza o fato de que as mudanças de configuração "pesaram o fardo" da governança imperial dos territórios sob mandatos:

ao oferecer uma plataforma para vociferantes hu-
manitaristas, revisionistas alemães beligerantes, e
nacionalistas determinados a expôr as brutalidades
do domínio imperial, o sistema de mandatos não
só minou a autoridade imperial, mas também - e
possivelmente de modo mais importante - levou
a que ao menos alguns no interior das potências
imperiais europeias questionassem se o domínio
direto era afinal tão desejável. Que a maior parte
dos habitantes locais não tivessem estima pelo sis-
tema de mandatos parece evidente. Com o tempo,
porém, muitas das potências imperiais também per-
deram sua simpatia por ele.

Feita essa ressalva, é importante observar que a importância econômica dos territórios sob mandato para

the crisis of empire. Oxford: Oxford University Press, 2015, p. 399. 55 PEDERSEN, Susan. The guardians: the League of Nations and the crisis of empire. Oxford: Oxford University Press, 2015, p. 404. 56 PEDERSEN, Susan. The guardians: the League of Nations and the crisis of empire. Oxford: Oxford University Press, 2015. p. 404. Para a autora, as explicações históricas sobre o Sistema de Mandatos da Liga das Nações devem conjugar as relações entre "interesse geopolítico", de um lado, e a "força do escrutínio e 'conversa' internacionais", de outro. PEDERSEN, Susan. The guardians: the League of Nations and the crisis of empire. Oxford: Oxford University Press, 2015. p. 406.

57 PEDERSEN, Susan. The guardians: the League of Nations and the crisis of empire. Oxford: Oxford University Press, 2015. p. 4.

58 PEDERSEN, Susan. The guardians: the League of Nations and the crisis of empire. Oxford: Oxford University Press, 2015. p. 13. as potências que os administravam não pôde ser apagada pelo discurso de missão civilizadora incorporado pelo direito internacional. Formalmente, a missão consistiria em "civilizar", e não em explorar os mandatos. Porém, a empreitada colonial, assim prorrogada, continuava a cumprir funções econômicas e estratégicas para as metrópoles, que agora se apresentavam sob o status jurídico de potências mandatárias. $\mathrm{O}$ acesso a matérias-primas representava tanto a segurança alimentar para a Europa quanto o suprimento de suas cadeias de produção industrial, ao passo que a abertura de novos mercados consumidores era necessária para escoar a produção. Não se pode perder de vista que a Europa, "em casa", contava com pressões de populações já urbanizadas, mais politicamente organizadas, e que clamavam por pleno emprego e melhoria das condições sociais. Anghie ${ }^{59}$ traz como exemplo disto a fala "sem rodeios" de Frederick Lugard (1858-1945), cuja "expertise" como conquistador colonial britânico e administrador de Hong Kong e da Nigéria foi, significativamente, aproveitada na Comissão Permanente de Mandatos da Liga das Nações. "As democracias de hoje pedem o direito ao trabalho, e a satisfação deste direito é impossível sem as matérias-primas dos trópicos, de um lado, e seus mercados, de outro."

Paralelamente a isto, os Estados Unidos, que não eram membros da Liga e, portanto, não integravam o Sistema de Mandatos, advogavam a "política de portas abertas" para todos os territórios administrados pelo esquema da Liga. "Isto asseguraria que todos os Estados pudessem comerciar e investir em pé de igualdade, e sem medo de discriminação, nos territórios sob mandato." ${ }^{60}$ Quer pelo acesso direto (isto é, tornando-se potência mandatária), quer pelo indireto (via liberdade comercial), os recursos coloniais ou dos territórios sob mandato eram cobiçados pelas potências centrais.

Embora o Sistema de Mandatos tenha sido feito em nome do princípio da autodeterminação dos povos, uma das principais bandeiras do idealismo wilsoniano, ${ }^{61}$ apenas o Iraque, como anteriormente apontado, conseguiu independência formal durante sua vigência. Para os demais, o Sistema de Mandatos foi a prorrogação dos 59 ANGHIE, Antony. Imperialism, sovereignty, and the making of inter-
national law. Cambridge: Cambridge University Press, 2004. p. 158.
60 ANGHIE, Antony. Imperialism, sovereignty, and the making of inter-
national law. Cambridge: Cambridge University Press, 2004. p. 143.
61 ANGHIE, Antony. Imperialism, sovereignty, and the making of interna-
tional law. Cambridge: Cambridge University Press, 2004. p. 139-40. 
arranjos coloniais da fase anterior do direito internacional clássico. Ele representou a reformulação jurídica, e não a extinção, das práticas coloniais. ${ }^{62}$

Como Anghie ${ }^{63}$ destaca, a configuração do direito internacional do Sistema de Mandatos é paradoxal. Por um lado, sua motivação é estabelecida em torno do princípio da autodeterminação dos povos. Depreende-se da missão civilizadora envolvida nos mandatos o projeto pedagógico europeu em relação à organização das sociedades atrasadas no formato político Estado, de rule of law, e de sociedade de mercado. Por outro lado, transparece a importância econômica e estratégica dos mandatos para as metrópoles, como partes de seu próprio modelo de desenvolvimento e conectados a suas estruturas sociais. A partir desse outro aspecto, torna-se difícil visualizar como os mandatos poderiam ter efetivamente promovido o autogoverno. Ao passo que o discurso jurídico é de emancipação, as formas jurídicas e a necessidade econômica envolvida nos mandatos em pouco ou nada favoreciam a autodeterminação. $\mathrm{O}$ mandato foi a atualização, no período entreguerras, de categorias jurídicas de universalização do direito internacional europeu via assimilação de povos não europeus: como as colônias e os protetorados. Nesse momento do entreguerras, a colonização contou com a possibilidade, o apelo moral de ser feita em nome da comunidade internacional, e não apenas da potência colonizadora.

Focalizar, apenas, o propósito anunciado (de autodeterminação dos tutelados) do Sistema de Mandatos pode conduzir à interpretação de que este falhou. No entanto, essa interpretação pode facilmente ser descartada em favor de outra, que observa a funcionalidade econômica e estratégica do Sistema de Mandatos: como mecanismo jurídico de legitimação do domínio e expansão do comércio dos países avançados. É ainda possível acrescentar o aspecto apontado por Susan Pedersen: a institucionalização e a internacionalização das relações coloniais sob a Liga das Nações permitiram a configuração de uma "esfera de contestação" que contribuiu para minar a legitimidade do arranjo entre as potências imperiais europeias. Mas o direito internacional dos anos do entreguerras foi incapaz de tornar realidade, em outro aspecto, sua concepção de segurança coletiva, cujos

\footnotetext{
${ }^{62}$ ANGHIE, Antony. Imperialism, sovereignty, and the making of international law. Cambridge: Cambridge University Press, 2004. p. 178.

63 ANGHIE, Antony. Imperialism, sovereignty, and the making of international law. Cambridge: Cambridge University Press, 2004. p. 144.
}

problemas estão relacionados preponderantemente às relações das grandes potências entre si.

\section{A derrocada do direito internacional do período entreguerras como técnica de paz}

Edward Carr ${ }^{64}$ atribuiu o fracasso do projeto de segurança coletiva da Liga das Nações ao caráter idealista ou utópico das aspirações wilsonianas. Viu nesse idealismo elementos de perigo: seu divórcio em relação à realidade deveria ser suprimido pela postura realista, apresentada como mais apropriada a informar concepções de segurança. O argumento remonta, facilmente, à lógica de Maquiavel: aquele que pretende fazer profissão de bondade, entre tantos que são maus, antes alcança a própria ruína. ${ }^{65}$ Este é o anúncio da perda de espaço do direito internacional para a teoria das relações internacionais como conhecimento informativo da ordem entre os Estados (e como discurso para representá-la). Outra possibilidade de leitura enfatiza pontos em que o projeto wilsoniano, sobretudo quanto à Liga das $\mathrm{Na}$ ções, não se completou como previsto: suas aspirações de mundo governado pelo direito foram minadas por inserções interpretativas baseadas em prioridades políticas dos Estados. O sentido é o de que, ignorando ou contrariando o projeto de substituir o arbítrio estatal pelo judicial, os Estados crescentemente submeteram às provisões do Pacto da Liga ao autojulgamento soberano estatal.

Nesse sentido, Michael Sheehan ${ }^{66}$ aponta o modo como o artigo 10 do Pacto da Liga das Nações foi inoperante. O dispositivo, como se viu, afirmava a integridade territorial e a independência política dos membros, atribuindo o dever de responder coletivamente em caso de agressão a um deles. Na prática, a interpretação conferida ao artigo foi a de que caberia aos próprios Estados, cada qual em seu juízo, decidir que ações deveriam ser tomadas, não implicando obrigação de ir à guerra em defesa do Estado atacado. Embora tenha sido invocado diversas vezes, o artigo nunca foi aplicado na prá-

${ }^{64}$ CARR, Edward Hallett. The twenty years' crisis 1919-1939: an introduction to the study of international relations. London: Macmillan \& Co., 1946.

${ }^{65}$ MAQUIAVEL, Nicolau. O príncipe. Brasília: Editora UnB, 1979.

${ }^{6}$ SHEEHAN, Michael. The balance of power: history \& theory. London/New York: Routledge, 2005. 
tica: não gerou resposta coletiva a atos de guerra contra membros. O Japão atacou a China, tomando a região da Manchúria, em 1931, e a Liga não enviou tropas em seu socorro. A fraqueza da Europa pós-crise de 1929 pode estar associada à falha em ativar o mecanismo de segurança coletiva. Mas o fato permanece de que o disposto no Pacto não funcionou. ${ }^{67}$

Igualmente problemático tornou-se o artigo 16, segundo o qual o membro que fizesse ataque em desrespeito a suas obrigações diante do Pacto, como procurar primeiro a solução pacífica de controvérsias (prevista nos artigos 12 a 15), seria considerado como tendo cometido ato de guerra contra os demais membros da Liga. Como resultado, sanções comerciais, financeiras e de restrição ao trânsito de pessoas deveriam ser imediatamente impostas. Em 1921, porém, a Assembleia da Liga resolveu que caberia aos próprios membros (e não à Liga em si) decidir se os artigos 12 a 15 (solução pacífica de controvérsias) haviam sido violados, e que não havia obrigação automática de engajamento em guerra coletiva.

O artigo 16 só foi implementado uma vez, contra a Itália após sua invasão da Abissínia em 1935. Os membros da Liga não impuseram todas as sanções imediatas, e os seus esforços minguados falharam em impressionar a Itália, levando a uma quebra da confiança na Liga e na segurança coletiva. ${ }^{68}$

Para além desses problemas, a Liga foi politicamente esvaziada. A principal potência econômica e militar da época ficou de fora desde o início. Outras potências se retiraram, como o Japão e a Alemanha, em 1933, a Itália, em 1937. A Liga mostrou apenas formalmente os seus “dentes" em 1939, ao expulsar a União Soviética após a invasão da Finlândia. ${ }^{69}$ Mas até lá, já havia se provado incapaz de efetivamente conter a violência nas relações internacionais. O projeto juridicamente informado de segurança coletiva pressupunha a adesão das potências, de modo que nenhuma, sozinha, fosse mais forte que a aliança formada. ${ }^{70}$ Mas muitas das principais

\footnotetext{
${ }^{67}$ SHEEHAN, Michael. The balance of power: history \& theory. London/New York: Routledge, 2005. p. 159-60; KOSKENNIEMI, Martti. The gentle civilizer of nations: the rise and fall of international law 1870 - 1960. Cambridge: Cambridge University Press, 2004. p. 378.

68 SHEEHAN, Michael. The balance of power: history \& theory. London/New York: Routledge, 2005. p. 159-60.

69 GINNEKEN, Anique H. M. van. Historical dictionary of the League of Nations. Lanham: The Scarecrow Press, 2006. p. 20.

${ }_{70}$ SHEEHAN, Michael. The balance of power: history \& theory. Lon-
}

potências já estavam fora da Liga quando a guerra eclodiu, em 1939.

\section{Considerações finais}

Os elementos trazidos nas seções anteriores permitiram observar que, após a Primeira Guerra Mundial o direito internacional público experimentou um processo de significativo adensamento institucional.

No campo da segurança internacional, o adensamento institucional se deu pelo estabelecimento da concepção de segurança coletiva. Referida concepção era juridicamente informada: baseava-se no compromisso estabelecido em tratado internacional e manejado por uma organização internacional de resposta coletiva a agressões sofridas por quaisquer de seus membros. Emergia um projeto de paz fundado na normatividade jurídica, não mais na confiança na operação espontânea do sistema de balanço de poder, característico do concerto europeu posterior às guerras napoleônicas, e que marcaram o século XIX na Europa. O balanço de poder, como visto, foi encarado pelos juristas internacionalistas membros do IDI como um estágio inferior na construção da ordem internacional, que teria em seu ápice o rule of law e o estabelecimento de uma jurisdição permanente como mecanismos para a paz. O projeto de relações internacionais informadas por bases jurídicas (e morais) também compunha o idealismo wilsoniano que, apesar de influente sobre a estruturação da Liga das Nações, não logrou atingir a participação dos próprios Estados Unidos no sistema de segurança coletiva concebido em 1919.

Outro adensamento institucional característico do momento entreguerras, como visto, correspondeu à emergência de novas organizações internacionais e à demanda por juristas internacionalistas. O impulso multilateral e rumo ao estabelecimento de uma jurisdição permanente e universal criou ambientes de trabalho para os profissionais identificados com o direito internacional. Por sua vez, a moldura cognitiva dos internacionalistas da época reforçou o processo de institucionalização, dado que partilhavam da crença na superioridade do modo judicial de solução de conflitos, na necessidade de estabelecimento de uma jurisdição

don/New York: Routledge, 2005. p. 161. 
permanente, com competência universal e compulsória e de desenvolvimento gradual do direito como projeto de paz. Ou seja, de manejo juridicamente institucionalizado das relações internacionais. Para além de aspectos ideacionais, os juristas internacionalistas estavam situados de modo a influenciar na prática a demanda por instituições multilaterais e solução pacífica de controvérsias — por sua atuação como agentes públicos nos Estados ou aconselhamento jurídico destes — e, ao mesmo tempo, a prover a força de trabalho para satisfazê-la — alçando cargos e posições em organizações internacionais, de solução de controvérsias e em espaços de formação em direito internacional.

No período do entreguerras, a institucionalização também marcou o modo como o direito internacional público estruturou o manejo dos povos não soberanos. Se, no século XIX, as categorias do direito internacional haviam abrigado o domínio metropolitano sob a formatação de colônias e protetorados, com a Liga das $\mathrm{Na}$ ções houve a estruturação de um Sistema de Mandatos. A adaptação acompanhou uma nova ordem jurídica discursivamente embasada na noção de comunidade internacional e com impulso multilateral. Mas preservou, em seu conteúdo, correspondências com o modelo anterior. Assim, os mandatos "A" eram a reedição do protetorado. Os mandatos "B", das colônias. E os mandatos " $\mathrm{C}$ ", da conquista por anexação. Diferentemente do modelo anterior, porém, o manejo dos povos não soberanos passou a ser feito em nome do interesse coletivo da comunidade internacional de Estados e de maneira institucionalizada, abrigada por uma organização internacional e por tratado, em contraste com o modelo característico do século XIX e séculos anteriores, de domínio direto pela metrópole sobre suas colônias, ou indireto sobre seus protetorados.

A caracterização da institucionalização do direito internacional público nesse período não pode ser encarada como sinônimo de sucesso do projeto de instrução jurídica da segurança internacional nele embutido. Tampouco a institucionalização do manejo dos povos não soberanos resultou na conquista da independência e da soberania formal por estes, com a única exceção do Iraque. Cabe, a esse respeito, a ressalva embasada no relato de Susan Pedersen, no sentido de que a institucionalização e a internacionalização das relações coloniais acabaram por conformar uma arena de contestação (a Comissão de Mandatos da Liga das Nações) e implicou desgaste do novo modelo de domínio imperial pelas po- tências coloniais europeias do passado. A par disso, no que diz respeito à segurança internacional, a não participação dos Estados Unidos na Liga, a inoperância dos artigos 10 (que fixava o dever de resposta coletiva à agressão sofrida por um de seus membros) e 16 do Pacto da Liga das Nações (segundo o qual o membro que recorresse à ataques bélicos sem antes procurar a solução pacífica de controvérsias seria considerado como tendo cometido ato de guerra contra os demais membros) e o progressivo esvaziamento político da Liga, no decorrer da década de 1939, representaram sua incapacidade prática de conter a violência nas relações internacionais com base no projeto juridicamente informado de segurança coletiva.

Desse modo, é possível notar o que institucionalização do direito internacional público é uma característica definidora de sua trajetória nos anos do entreguerras. É particularmente relevante que o movimento de institucionalização do direito internacional do período do entreguerras tenha refletido assimetrias entre povos que estiveram na base da própria emergência do direito internacional público como campo autônomo no século XIX. Um aspecto saliente consiste na própria exclusão dos povos considerados subalternos da composição da Liga das Nações, organização internacional formalmente classificada como universal. Afinal, povos da África e Ásia estavam em sua maior parte sob domínio europeu, e não eram dotados de soberania formal para participar da Liga. No Sistema de Mandatos, participavam apenas como objetos: a ausência de capacidade para provocação dos mecanismos da Comissão de Mandatos é evidenciada pelo fato de que não tinham direito de submeter petições diretamente à organização internacional. Para além disso, do linguajar adotado para qualificação de fontes no Estatuto da Corte Permanente de Justiça Internacional até a configuração do Sistema de Mandatos, verificam-se as marcas de concepções implícitas de hierarquias assentadas em bases culturais e raciais, características do encontro colonial.

A juridificação tanto do projeto de paz quanto do manejo dos não soberanos no período do entreguerras, acompanhada pelo abrigo dessas questões no âmbito de organizações internacionais, não pode ser confundida com a afirmação de que o projeto de ordenação jurídica das relações internacionais tenha sido bem-sucedido nessas aspirações. A eclosão da Segunda Guerra Mundial contestou o projeto de paz, e o Sistema de Mandatos foi marcado pela preservação da negação da 
soberania como regra, e a conquista da independência como exceção.

No Pós-Segunda Guerra Mundial, a densidade jurídica no projeto de paz dos anos do entreguerras seria formalmente reeditada e modulada numa nova concepção de segurança coletiva manejada por grandes potências com poder de veto e abrigada por uma organização multilateral: a Organização das Nações Unidas. No entanto, em poucos anos, o projeto de segurança coletiva da Carta de São Francisco, apesar de sua permanência formal, perdeu lugar para espaços institucionais e práticas informais orientadas pela teoria das relações internacionais, de inspiração no realismo político e não na linguagem dos juristas internacionalistas, e pela estratégia de dissuasão fundada no balanço nuclear de terror, com o início da Guerra Fria.

\section{Referências}

AFONSO, Henrique Weil. A era da humanidade: reflexões para a história do direito internacional. Revista de Direito Internacional, Brasília, v. 13, n. 3, p. 235-262, 2016. DOI: https://doi.org/10.5102/rdi/bjil.v13i3.4222

ANGHIE, Antony. Imperialism, sovereignty, and the making of international law. Cambridge: Cambridge University Press, 2004.

BOYLE, Francis Anthony. World politics and international law. Durham: Duke University Press, 1985.

CARR, Edward Hallett. The twenty years' crisis 1919-1939: an introduction to the study of international relations. London: Macmillan \& Co., 1946.

CASTRO, Marcus Faro de. Formas jurídicas e mudança social: interações entre o direito, a filosofia, a política e a economia. São Paulo: Saraiva, 2012.

FERREIRA, Hugo Luís Pena. Formas jurídicas do encontro colonial: violência e hierarquias entre povos no direito internacional do século XIX e início do século XX. Revista Jurídica da UFERSA, v. 2, n. 3, p. 48-69, 2018. DOI: https://doi.org/10.21708/issn2526-9488. v2.n3.p48-69.2018

GALINDO, George Rodrigo Bandeira. Para que serve a história do direito internacional? Revista de Direito Internacional, Brasília, v. 12, n. 1, p. 338-354, 2015. DOI: https://doi.org/10.5102/rdi.v12i1.3368
GINNEKEN, Anique H. M. van. Historical dictionary of the League of Nations. Lanham: The Scarecrow Press, 2006.

HILLIER, Tim. Sourcebook on public international law. London: Cavendish Publishing, 1998.

IKENBERRY, John G. After victory: institutions, strategic restraint, and the rebuilding of order after major wars. Princeton: Princeton University Press, 2001.

KAPLAN, Morton A.; KATZENBACH, Nicholas B. Fundamentos politicos do direito internacional. Rio de Janeiro: Zahar, 1964.

KEOHANE, Robert O. After hegemony: cooperation and discord in the world political economy. Princeton: Princeton University Press, 1984.

KEYNES, John Maynard. As consequências econômicas da paz: São Paulo/Brasília: Imprensa Oficial do Estado/ Universidade de Brasília, 2002 [1919].

KOSKENNIEMI, Martti. Entre a apologia e a utopia: A política do direito internacional. Revista de Direito Internacional, Brasília, v. 15, n. 1, p. 5-29, 2018. DOI: https:/ / doi.org/10.5102/rdi.v15i1.4993

KOSKENNIEMI, Martti. The gentle civilizer of nations: the rise and fall of international law 1870 - 1960. Cambridge: Cambridge University Press, 2004.

LEMOS, Fabrício José Rodrigues de; SARTORETTOO, Laura Madrid. Resenha do livro Imperialism, Sovereignty and the Making of International Law, de Antony Anghie. Revista de Direito Internacional, Brasília, v. 15, n. 1, p. 305-308, 2018.DOI: https://doi.org/10.5102/rdi. v15i1.4911

MAQUIAVEL, Nicolau. O príncipe. Brasília: Editora UnB, 1979 [1513].

PEDERSEN, Susan. The guardians: the League of $\mathrm{Na}$ tions and the crisis of empire. Oxford: Oxford University Press, 2015.

POLANYI, Karl. The great transformation: the political and economic origins of our time. 2. ed. Boston: Beacon Press, 2001 [1944].

SACRISTE, Guillaume; VAUCHEZ, Antoine. The force of international law: lawyers' diplomacy on the international scene in the 1920s. Law \& Social Inquiry, v. 32, n. 1, p. 83-107, 2007. DOI: https://doi.org/10.1111/ j.1747-4469.2007.00051.x 
SHEEHAN, Michael. The balance of power: history \& theory. London/New York: Routledge, 2005.

SHINOHARA, Hatsu. US international lanyers in the interwar years: a fogotten crusade. Cambridge: Cambridge University Press, 2012.

SKOUTERIS, Thomas. The vocabulary of progress in interwar international law: an intellectual portrait of Stelios Seferiades. European Journal of International Law, v. 16, n. 5, p. 823-856, 2006. DOI: https://doi. org/10.1093/ejil/chi157

TRIGO, Germán Medardo Sandoval. La libre autodeterminación de los pueblos en el siglo XXI: Una aproximación de la historia del colonialismo y el neocolonialismo desde los pueblos del tercer mundo en el derecho internacional. Revista de Direito Internacional, Brasília, v. 15, n. 1, p. 90-104, 2018. DOI: https://doi. org/10.5102/rdi.v15i1.4986 
Para publicar na Revista de Direito Internacional, acesse o endereço eletrônico www.rdi.uniceub.br ou www.brazilianjournal.org.

Observe as normas de publicação, para facilitar e agilizar o trabalho de edição. 